\title{
Civic Engagement with an International Focus: The Western Carolina Microfinance Project
}

Michael K. McDonald, Western Carolina University

ABSTRACT Recent trends in political science include civic engagement and experiential education pedagogy, but this has been notably absent from courses on international relations and comparative politics. This article discusses how I designed an international civic engagement experience for students-without leaving campus. I echo other scholars' claim that civic engagement pedagogy can and should be used in courses with an international focus, and I provide one example of how to go about that task.

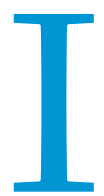
$\mathrm{n}$ recent years, educators have paid increasing attention to civic engagement pedagogy in college political science classes (Dicklitch 2003; Koulish 1998; McCartney 2006, 2011; Patterson 2000). Through innovative methods, including service-learning and experiential education courses, political scientists have worked to increase our students' sense of civic responsibility and engage them as participants in civic life.

With a few notable exceptions discussed later, most of this effort to include civic engagement in political science classes has been based in the American politics subfield. This trend is neither surprising nor undesirable. It is easy to see how a civic engagement pedagogy fits well with many state and local government classes, courses on public policy, and other courses with material that is "close to home." However, as Alison McCartney has noted, courses with an international focus have largely been excluded from this effort, “... perhaps because the subject is seen as too remote or too difficult to translate into a civic engagement, service-learning (CESL) course or because educators simply do not know how to do it" (McCartney 2006, 115).

The goal of this article is to echo other scholars' claim that civic engagement pedagogy can and should be used effectively in international relations courses as well as report on an innovative course that provides a truly international civic engagement experience to students without leaving campus. My hope is that this article will provide a potential framework, a relatively new technological tool, and a set of recommendations based on lessons learned to educators who plan to include civic engagement methodology in international relations courses.

Michael K. McDonald is a visiting assistant professor in the department of political science and public affairs at Western Carolina University and a doctoral candidate in the department of government and politics at the University of Maryland. He can be reached at mkmcdonald@wcu.edu.

\section{CIVIC ENGAGEMENT PEDAGOGY IN INTERNATIONAL RELATIONS}

The concept of including civic engagement pedagogy in international relations classes is not new. Amy Patterson offered one prominent example more than a decade ago, incorporating a service-learning project into her upper-level international relations course (Patterson 200o). Patterson's students assembled new arrival packages to assist immigrants who had recently moved to the area. About the same time, two similar examples also appeared in this journal. While not specifically attempting to integrate civic engagement and international relations, both examples accomplished that goal. Robert Koulish reported on the Bentley Immigrant Assistance Program organized through the Service Learning Center at Bentley College (Koulish 1998). Students participating in the program assisted local immigrants in their transition to life in the United States. Similarly, Susan Dicklitch reported on a senior-level political science seminar she designed called "Human Rights/Human Wrongs," in which students learned about the asylum process and worked on foreigner's asylum applications in cooperation with a local nongovernmental organization (NGO) (Dicklitch 2003).

All three of these unique opportunities are what Luis Cabrera and Jeffrey Anastasi have called "place-bound interaction" approaches to global civic engagement (Cabrera and Anastasi 2008; see also Lorenzini 2010). In place-bound interactions, students enhance their sense of civic engagement by rendering services to immigrants newly arrived in their community. Place-bound interaction is contrasted with two other approaches to global civic engagement: transborder service learning, in which students serve a population located across an international boundary, and what is commonly called international service learning, in which students travel to another country and participate in service-learning opportunities while abroad (Cabrera and Anastasi 2008).

All three of these efforts at global civic engagement aim to integrate an international component into a political science 
course. Recently, Alison McCartney has written about a related, but innovative approach (McCartney 2006, 2011). McCartney works with international relations students to host a high school Model United Nations conference every year. The students apply what they have learned in class by working closely with the high school teams to prepare them to participate in the conference. In a creative way, McCartney's program allows students to experience the local impact of international relations in their own community.

A few other examples of international civic engagement are worth mentioning. Lynn Metcalf of The Orfalea College of Business at California Polytechnic State University reports on her capstone marketing course, in which students operate a collegiate chapter of a NGO engaged in international community service (Metcalf 2010). While not a political science course, Metcalf's marketing course recognizes the benefits of an international service learning experience for her students. Finally, Michelle Lorenzini reports on the Atlas Program at Saint Louis University (Lorenzini 2010). A co-curricular program, the Atlas Program reaches students in a variety of majors and focuses on informed advocacy as a pedagogical tool to encourage international civic engagement among students.

All of these examples share a common focus: global civic engagement. However, most of them share another commonality: they incorporate civic engagement and international relations at the local level-by engaging with immigrants in the community, teaching high school students about international relations, or

\section{Course Goals}

At the outset of the course, four core learning objectives were established. Students were expected to:

1. Develop their critical thinking, oral communication, and written communication skills;

2. Develop leadership and project management skills;

3. Acquire a substantive knowledge of international development and microfinance; and

4. Participate in a service-learning and civic engagement project.

Underlying all of these goals is the intention, common in the literature, for students to develop a stronger sense of social and civic responsibility and a desire to contribute to their global community in the future.

For the most part qualitative examination of these goals at the conclusion of the course leads me to believe that most students succeeded in developing new knowledge about development issues as well as new skills related to organizing the project.

\section{Course Design and Logistics}

To achieve the four learning objectives, I structured the course around four components. First, students were assigned weekly readings, and each Monday morning they participated in a discussion of those readings. To encourage them to read critically, they submitted a one- to two-page reading response prior to each class.

\section{Underlying all of these goals is the intention, common in the literature, for students to develop a stronger sense of social and civic responsibility and a desire to contribute to their global community in the future.}

working and advocating for particular international issues and causes. One goal of this article is to suggest that we truly can do transborder global civic engagement with a focus on people living in the developing world through innovative technologies. Without traveling abroad, students in international relations courses can interact with individuals in the developing world and have a truly international service-learning experience.

\section{THE WESTERN CAROLINA MICROFINANCE PROJECT}

During the fall 2011 semester I taught a one-credit civic engagement class. The civic engagement course is a major requirement that usually includes a service-learning project. In the past, this course has been taught largely by public policy faculty or faculty who teach in American politics. My course focused on microfinance as a tool for development in the poorest parts of the world. Students spent the first several weeks of the semester reading about international development and the roots of microfinance. During the middle of the semester, while continuing weekly readings and discussion, the focus shifted to fundraising. The students worked together to raise funds, which they would ultimately use to provide microloans to individuals in the developing world. After fundraising was completed, the students identified worthy loan recipients and extended loans to them. As the initial loans were repaid, the students re-invested those payments in additional development projects.
The second component involved fundraising. Rather than having the university provide a set budget, I required students to raise their own money. This approach provided several benefits. First, in a time of cash-strapped university budgets, having students raise funds for the project made the class more feasible and practical. Second, by raising their own funds, students were required to commit their time and effort to the project in a meaningful way. Third, fundraising is a valuable, marketable, and transferrable vocational skill. Students were able to understand and participate in one fundamental step that NGOs and other development organizations must go through in order to "do good." Involving students in the fundraising and budget-making process encouraged buy-in to the overall project while serving a meaningful pedagogical purpose.

The third component involved identifying a project or projects in which to invest the money students raised. We used a thirdparty, online platform called Kiva to facilitate our loans. Kiva's objective is to connect users who are interested in helping people in the developing world with partners on the ground who facilitate microloans. Kiva is a US-based 501 (c) 3 nonprofit organization that works with local "field partners," usually development NGOs, that review loan applications and approve borrowers who demonstrate a specific need and reasonable likelihood of repayment. As of June 2013, Kiva has more than 1.4 million online users (almost a million of whom have funded a loan) and 194 field 
partners in 68 countries. In terms of risk and default rates, Kiva and its field partners demonstrate striking success. Again, as of June 2013, Kiva's total loans amount to more than $\$ 438$ million with a repayment rate of $99.01 \%$ ("Kiva").

After the fundraising portion of the project was complete, students spent about a week reviewing all the projects listed on Kiva's website and identifying several that they would like to fund. In the discussion section I provide additional details about our loan recipients.

The fourth and final component of the course involved monitoring the repayment process and ultimately re-lending money that was repaid from the initial loans.

\section{Academic Content}

One major goal in constructing the microfinance course was to ensure that the course would include a rigorous academic component in addition to the service-learning and civic engagement pedagogy. This requirement was met primarily through weekly readings and discussion. Students read almost all of Muhammad Yunus' book Banker to the Poor about the evolution of microfinance and the founding of Grameen Bank (Yunus 2007). Yunus' book is both engaging in its narrative style and informative for students who know little about microfinance and the history of this development tool.

Additionally, they read two chapters from Asif Dowla and Dipal Barua's book The Poor Always Pay Back, which focuses on changes made to the initial Grameen Bank model and efforts to increase both the efficacy of microloans and the ability of loan recipients to repay (Dowla and Barua 2006). Students were then exposed to some economic theory through Beatriz Armendariz and Jonathan Morduch's graduate-level econometric text The Economics of Microfinance (Armendariz and Morduch 2010), followed by a much more practical real-world example of microfinance at work in a Harvard Pew Center case study on an effort in Haiti by a commercial bank to get into the microfinance game (Stuart 2002).

Finally, toward the end of the semester, students read critique and criticism of microfinance, including several chapters of Thomas Dichter and Malcolm Harper's book What's Wrong with Microfinance (Dichter and Harper 2007). Because there are many critics of microfinance, I wanted students to be exposed to arguments against the model as well. Many students found these readings to be the most helpful in rounding out their knowledge of the pros and cons of microfinance.

For each of these readings, students were given questions or topics to consider and were asked to submit a reaction paper in advance of our class discussion. In addition, half of their final reflection paper was dedicated to a synthesis of the academic content of the course. Students were asked what they learned about developing countries and microfinance and how the course material connected with other courses they had taken for the major.

\section{COURSE OUTCOMES AND DISCUSSION}

\section{Successes}

Both the civic engagement project and the course as a whole were successful. The students raised a total of \$306 and provided initial loans to two projects in developing countries, fully funding one of those projects. Descriptions of our two loan recipients are listed in figures $1 \mathrm{~A}$ and $1 \mathrm{~B}$.

The course itself was also a success. From class discussion and from the students' final reflection essay, clearly the experiential
Figure $1 \mathrm{~A}$

\section{Borrower A, the Philippines}

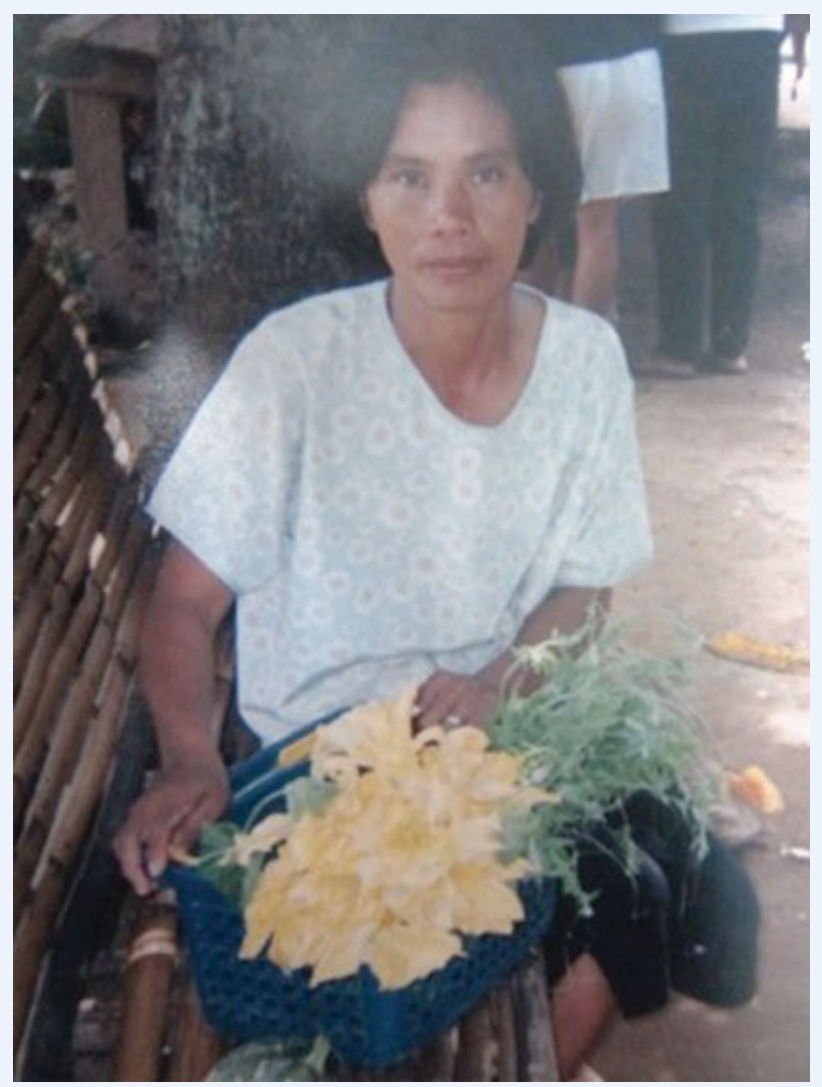

We loaned this recipient $\$ 250$, fully funding her microloan request. As of this writing, the loan has been repaid in full. (Color online.)

From Kiva

[Borrower A] is 45 years old and a married woman. She is a very loving mother with her children and spouse. She is very busy with her rolling store, offering a variety of vegetables to the people of the community. She sells house to house.

[Borrower A] is asking for a loan of PHP 10,000 to buy tomatoes, beans, leafy vegetables and fruits for her business. She dreams that someday she can construct her own stall for her business.

education component of the course enhanced student learning regarding microfinance and international development.

Anecdotally, I noticed a difference in the depth of knowledge students gained from the assigned reading. Having used some of the same material in previous courses, students in the civic engagement class demonstrated a deeper knowledge and more critical analysis of the reading than previous classes. Students related what they were reading to their own experience raising money and examining loan applications. While students in previous classes were too quick to accept microfinance as a solution to poverty and underdevelopment, students in the civic engagement class were more aware of the shortcomings and challenges of microfinance. One student wrote: "I feel confident that I have a good understanding of microfinance as a whole, the good, the bad, and the ugly." Another student echoed that sentiment, saying, "I now feel I have a better understanding of Microfinance's successes and failures."

In their final reflection essays, many students highlighted other ways the civic engagement pedagogy increased their level of understanding. Many students remarked on the unique opportunity 
Figure $1 B$

Borrower B, Zimbabwe

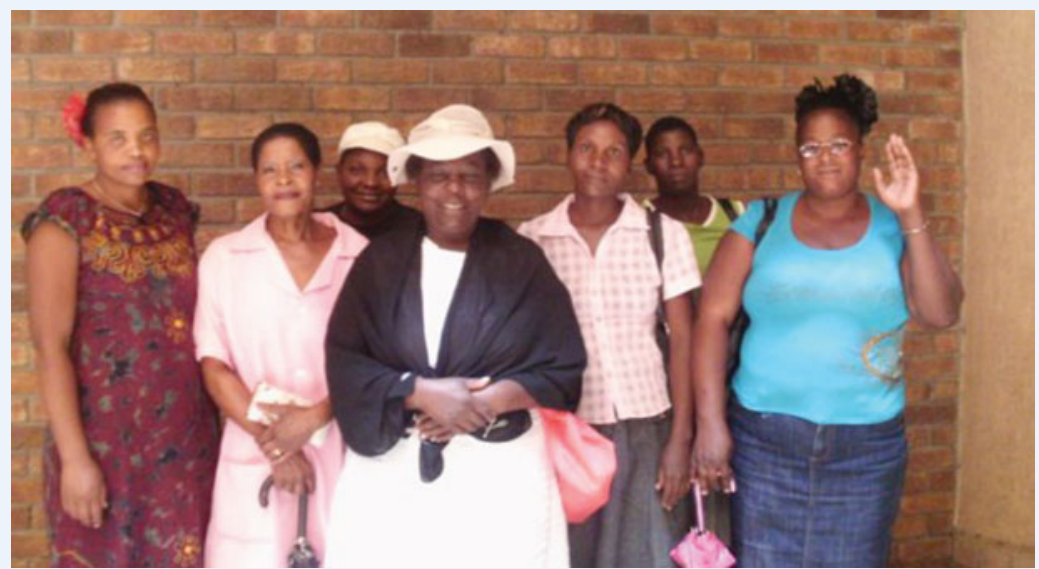

We loaned this recipient $\$ 75$. We were one of 102 lenders who contributed to fund the group, who together borrowed $\$ 2,800$. As of this writing, this loan has also been repaid in full. (Color online.)

From Kiva

[Borrower B] is 43 years old, single, and has one child who attends school. She has three other dependents (her sister's children). She operates a flea market stand in her town. She has been in business for six years and has one employee. She buys her products from South Africa and Botswana.

[Borrower B] is requesting a loan for $\$ 250$, which she will use to buy more clothes to sell. High competition in the market and some debtors failing to make payments on time are some of the challenges she faces in the business. With the profits from the business, she would be able to take better care of her child and save for their future. Her dream is to own a clothing store in the Central Business District area. on international development and poverty, the civic engagement project did all of this in a more meaningful way than traditional classroom activities such as reading and discussion.

The civic engagement project also accomplished an important goal I had overlooked when planning the class: overcoming the inevitable hopelessness students feel when examining topics as large and complex as global poverty. A student response captures this outcome perfectly:

Everyone seemed aware that the world was stricken with a large amount of poverty, but how to solve the problem certainly seemed unfathomable. Having a successful project helped each student to feel as though they accomplished what they set out to achieve.

Finally, students demonstrated both increased global competency and a sense of global citizenship. In all of my classes I strive for students to develop a more cosmopolitan identity as global citizens with a civic responsibility to those in their local, national, and global community. Including the international civic engagement project helped achieve that goal in a way other classes have not. One student exhibited broader global awareness, saying: the class presented to them. As one student put it, this project "allowed for a different type of critical thinking, analyzing, and community interaction that many would not have done otherwise." Student reflections also demonstrated in-depth learning in two particular areas: the reality of poverty in developing counties and the challenges NGOs and microfinance organizations face. Regarding the former, one student remarked:

We get so tied up in our lives and the struggles of our community and forget that the poorest among us are wealthy by the world standards. We spend more on our cup of coffee before class than people will make in a week. This is an issue that we as a country need to realize.

Concerning the challenges faced by these organizations, another student said:

The class decided on its own fundraising methods, executed them without oversight, and brought in enough funds to fully fund an entire project, rather than having to collaborate with another lender. This was a great learning mechanism, as it demonstrates the necessary skill for starting, building, and executing a project for both social and economic development.

Each of these student comments reflect the benefit of including civic engagement in the course, as well as the in-depth knowledge and critical analysis that came out of the experience. The civic engagement component helped students understand the reality of poverty in a unique way. Looking at borrower profiles on Kiva put a human face on the abstract concept, and the process of sending two individuals real-world money to fund real-world projects encouraged students to think about the daily lives of those who live in poverty. Comparing this experience to previous classes
This class also broke the stereotype in my mind that other countries do not have the same entrepreneurial spirit that we here in America do and that others around the world want to be able to move up in the social ladder by owning their own small business.

And another student exemplified the kind of global citizenship we seek:

Having international focused civic learning we are showing that a class at Western Carolina University in Cullowhee, North Carolina, is able to have an impact on the world. We are also showing that we are not only citizens of Cullowhee, North Carolina and the United States, but also citizens of the world. I think sometimes we as Americans forget that we are citizens of the world.

Given all of these student responses as well as my own reflection, I am confident that the inclusion of civic engagement with theory and traditional pedagogy led to better learning outcomes.

\section{Challenges and Lessons Learned}

Of course there are always challenges and areas for improvement. My hope is that this section of the article will be helpful for educators considering similar models in future classes.

One major challenge was that this was a one-credit course. In one-credit courses it can be difficult to find the appropriate workload that both respects students' time given the limited course credit and provides an academically rich and meaningful experience. That balance was even more difficult to strike in this class because I had not taught it before, and because the entire structure of the course was unique. This type of international civic engagement course surely deserves and needs to count for threecredits (or for institutions with different credit systems, the equivalent credit of other courses in the major). 
A second challenge was getting students to "buy in" to the idea of the course. I had anticipated that students would volunteer to lead different aspects of the project and different fundraising endeavors, but that did not happen. I had to convince several students to take leadership roles, and the result was an overall lack of leadership within the student group. For a project like this to be successful, it may be important for the instructor to design leadership into the course rather than assuming the active involvement of students.

Part of the problem was that I was adding a new design and pedagogy to an already-existing course. Many of the students came into the class with expectations about what the course would be like, and the new design did not meet those expectations. A lack of buy-in may also have resulted from the fact that this was a required class. Students did not necessarily have to take my section of the course during that particular semester, but they did have to take it at some point. In all likelihood, this factor probably led to a cohort of students less interested in the concepts and methodology of the course than if it was purely an elective. Whenever possible, this kind of international civic engagement class works best as an elective, with a cohort of students who truly care about the project. It would be best if students were required to apply for the class. If that is not possible, plenty of advance information about the content and methodology of the course should be provided so that students understand what the course involves. I will say that, by the end of the term, several of the more reticent students had embraced the idea of the course and became natural leaders in the group. I only wish they had performed that function from the outset.

A third challenge came with fundraising. At the beginning of the course, I encouraged the group to set their own fundraising goal. I told them to be ambitious but realistic. The group settled on a goal to raise $\$ 1500$. In retrospect, this was a rather unrealistic goal, especially given the previously mentioned initial lack of buyin. Rather than being an inspirational goal, the $\$ 1500$ mark acted as a discouragement to the students as they struggled to raise money. Because most of the group had no prior experience with fundraising, they did not know how difficult it would be and how much work it would require. Could a group of 17 students raise $\$ 1500$ ? Yes. However, setting a more realistic goal from the outset with the option of raising it later would have been a better approach. Students had some success raising money at a donation booth set up outside the student activity center, and one group attempted to produce a benefit concert that eventually failed to get off the ground. However, the most effective fundraising technique involved students visiting other classes and directly soliciting donations from fellow students and faculty members. In the end, the group raised \$306. With more effort on their part and more oversight of their fundraising efforts on my part, that amount could have been higher. That being said, $\$ 300$ is a meaningful sum of money, especially for our loan recipients.

\section{CONCLUSION}

Technology and online resources like Kiva provide a unique opportunity for integrating civic engagement and service learning pedagogy into international relations courses and curriculum. The course described in this article offers one example of how to structure such a project, as well as a few of the lessons I learned in the process of teaching the class. In the end, I believe the course was a great success and substantially improved student learning. I would encourage other professors of international relations, comparative politics, or international development to consider similar approaches.

\section{REFERENCES}

Armendariz, Beatriz, and Jonathan Morduch. 2010. The Economics of Microfinance, 2nd Ed. Cambridge, MA: MIT Press.

Cabrera, Luis, and Jeffrey Anastasi. 2008. “Transborder Service Learning: New Fronteras in Civic Engagement.” PS: Political Science and Politics 41 (2): 393-99.

Dichter, Thomas, and Malcolm Harper, eds. 2007. What's Wrong with Microfinance? Warwickshire, UK: Practical Action Publishing.

Dicklitch, Susan. 2003. "Real Service = Real Learning: Making Political Science Relevant Through Service-Learning." PS: Political Science and Politics 36 (4): $773-76$.

Dowla, Asif, and Dipal Barua. 20o6. The Poor Always Pay Back: The Grameen II Story. Bloomfield, CT: Kumarian Press.

"Kiva." http://www.kiva.org.

Koulish, Robert. 1998. "Citizenship Service Learning: Becoming Citizens by Assisting Immigrants." PS: Political Science and Politics 31 (3): 562-67.

Lorenzini, Michelle S. 2010. "From Global Knowledge to Global Civic Engagement. APSA 2010 Teaching and Learning Conference Paper." Available at SSRN: http://ssrn.com/abstract $=1545531$ or http://dx.doi.org/10.2139 /ssrn.1545531

McCartney, Alison R.M. 2006. "Making the World Real: Using a Civic Engagement Course to Bring Home Our Global Connections." Journal of Political Science Education 2: 113-28.

. 2011. "Connecting Civic Engagement and International Relations Pedagogy: An Effective Combination? APSA Annual Conference Paper." Available at SSRN: http://ssrn.com/abstract $=1919865$.

Metcalf, Lynn E. 2010. "Creating International Community Service Learning Experiences in a Capstone Marketing-Projects Course." Journal of Marketing Education 32 (2): 155-71.

Patterson, Amy. 200o. "It's a Small World: Incorporating Service Learning into International Relations Courses.” PS: Political Science and Politics 33 (4): 817-22.

Stuart, Guy. 2002. "A Commercial Bank Does Microfinance: Sogesol in Haiti." Kennedy School of Government Case Program, CR16-02-1657.0. Cambridge, MA: Harvard University Kennedy School of Government.

Yunus, Muhammad. 2007. Banker to the Poor: Micro-Lending and the Battle against World Poverty. New York: PublicAffairs. 